\title{
Projection of participant recruitment to primary care research
}

\author{
David White*, Daniel Hind \\ From 3rd International Clinical Trials Methodology Conference \\ Glasgow, UK. 16-17 November 2015
}

\section{Background}

Recruitment to clinical trials remains challenging, particularly in primary care settings. Initial projections of participant recruitment should be as accurate as possible, in order to avoid the financial, clinical and ethical costs of trial extensions or failures. However, estimation of recruitment rates is challenging and often poorly executed. We used qualitative methods to explore the experiences and views of researchers on the planning of recruitment in this setting.

\section{Methods}

Participants had registered accrual to a UK based primary care research study between April 2009 and March 2012. We interviewed ten chief investigators or study managers, using a semi-structured topic guide. Framework analysis was used.

\section{Results}

1) A large number of factors affecting recruitment rates were identified. Use of targeted mail-outs was preferred where possible, eliminating some of the uncertainty involved where direct clinician referrals are required. 2) The importance of qualitative and pilot work were stressed, but we identified some ambivalence as to the benefits of formulating detailed recruitment projections, as well as uncertainty as to how best to schedule trial timelines to maximise efficiency. 3) Several potential sources of bias involved in the estimation of recruitment rates were identified, including technological, psychological and political factors.

\section{Conclusions}

We found a large number of factors that impact on recruitment rates to primary care research, and highlighted the

University of Sheffield, Sheffield, UK

(c) 2015 White and Hind This is an Open Access article distributed under the terms of the Creative Commons Attribution License (http://creativecommons.org/licenses/by/4.0), which permits unrestricted use, distribution, and reproduction in any medium, provided the original work is properly cited. The Creative Commons Public Domain Dedication waiver (http://creativecommons.org/ publicdomain/zero/1.0/) applies to the data made available in this article, unless otherwise stated. complexity of realistic estimation. The use of wider distributional information may improve accuracy when estimating accrual rates. Further research is needed to develop a formal approach to eliminate biases in recruitment projection.

Published: 16 November 2015

doi:10.1186/1745-6215-16-S2-P120

Cite this article as: White and Hind: Projection of participant

Submit your next manuscript to BioMed Central and take full advantage of:

- Convenient online submission

- Thorough peer review

- No space constraints or color figure charges

- Immediate publication on acceptance

- Inclusion in PubMed, CAS, Scopus and Google Scholar

- Research which is freely available for redistribution recruitment to primary care research. Trials 2015 16(Suppl 2):P120. 